\title{
Tuorevihannesten tuotantotilojen pintahygienian selvittäminen
}

\author{
Risto Kuisma ${ }^{1}$, Hanna-Riitta Kymäläinen ${ }^{1}$, Marja Lehto ${ }^{2}$ \\ ${ }^{1}$ Helsingin yliopisto, maataloustieteiden laitos, PL 28 (Koetilantie 5), 00014 Helsingin yliopisto, \\ risto.kuisma@helsinki.fi,hanna.riitta.kymalainen@helsinki.fi \\ ${ }^{2}$ Luonnovarakeskus, Viikinkaari 4,00790 Helsinki,marja.lehto@luke.fi
}

\section{TIIVISTELMÄ}

Kasvikset on usein terveellistä syödä tuoreena. Kuluttajat ja suurkeittiöt haluavat yhä pidemmälle prosessoituja kasvistuotteita. Käsittelyketjussa tuorevihannekset käyvät läpi useita vaiheita, kuten pesun, esikäsittelyn, kuorinnan, pilkkomisen, huuhtelun ja pakkaamisen. Puutteet prosessointikäsittelyissä voivat edistää kasvisten pilaantumista ja edistää tautia aiheuttavien mikrobien päätymistä tuotteisiin prosessiveden, henkilöstön, laitteiden ja koneiden välityksellä. Omavalvonta, jossa hyödynnetään myös mikrobiologisia testausmenetelmiä, on tärkeä työkalu tuotantoprosessien turvallisuuden seurannassa. Tutkimuksessamme arvioitiin kuuden kasviksia jatkojalostavan yrityksen pintahygieniaa vuosina 2009 ja 2012. Ensimmäisen, vuoden 2009, hygieniakartoituksen jälkeen yrityksille kerrottiin kartoitustuloksista ja annettiin kehittämisehdotuksia. Jokaisesta yrityksestä otettiin tuotantotilojen puhdistamisen jälkeen 264-696 pintanäytettä samoista tuotantoympäristön mittauspisteistä käyttäen erilaisia mikrobiologisia ja yleishygieenisiä näytteenottomenetelmiä. Vertailemalla vuoden 2009 ja 2012 hygieniakartoituksien tuloksia keskenään havaittiin yleisesti ottaen tuotantotilojen pintojen puhtauden olevan paremmalla tasolla vuonna 2012. Visuaalisesti tarkastelemalla prosessointitiloissa oli tapahtunut näkyviä muutoksia vuoden 2009 hygieniakartoituksien jälkeen. Esimerkiksi lattiapintoja, kuljetinhihnoja ja leikkuulautoja oli paikoitellen uusittu, kenkien puhdistusjärjestelmiä oli otettu käyttöön eri hygienia-alueiden välillä sekä avoimia linjoja oli muutettu suljetummiksi. Vuosien 2009 ja 2012 tuloksia vertaamalla havaittiin kokonaismikrobimäärien sekä enterobakteerien, homeiden ja hiivojen vähentyneen tutkituilta pinnoilta. Sekä vuonna 2009 että 2012 hygieniakartoituksissa puhtauden kannalta ongelmallisimmiksi pinnoiksi osoittautuivat koneet ja laitteet sekä kuljettimien hihnat. Edellä mainitut pinnat on hygieniakartoituksissa todettu olevan tuotantohygienian kannalta mikrobiologinen vaaratekijä, joten näiden puhdistukseen tulee lisätä resursseja. Kasviksia pilkkovien laitosten on tarpeen kehittää puhdistus- ja hygieniakäytäntöjään edelleen, lisäksi työntekijöiden koulutusta ja puhdistuksen omavalvontaa olisi lisättävä. Tutkimus tehtiin"TUOVI" -hankkeessa, jonka rahoittivat Lounais-Suomen ELY-keskus ja useat yritykset. Maa- ja metsätalousministeriön rahoittamassa Hyviä käytäntöjä tuorekasviksia valmistaviin yrityksiin (TuoPro2) -hankkeessa pyritään kouluttamalla ja tiedottamalla auttamaan yrityksiä kehittämään tuotantohygieniaa.

Asiasanat: Tuorekasvikset, hygienia, pikamenetelmät, tuotantotila, puhtaus, puhdistus 


\section{Johdanto}

Suomessa kasvisten kulutus on lisääntynyt tasaisesti viime vuosikymmeninä. Vuoden 2013 ravintotaseen mukaan suomalaiset söivät vuodessa keskimäärin 60,9 kiloa tuoreita vihanneksia henkilöä kohden (Tike 2014). Prosessoitujen tuorekasvisten kulutus, kysyntä ja tarjonta ovat kasvaneet koko ajan kuluttajien ja suurkeittiöiden halutessa yhä pidemmälle jalostettuja raaka-aineita. Tuorekasvisten valikoimat ovat laajentuneet ja monipuolistuneet viime vuosina, mutta tuotteiden laadun optimointiin on kiinnitetty kuitenkin liian vähän huomiota. Kasviksia käsitellään ja jatkojalostetaan yhä enemmän jo alkutuotantotiloilla, mutta käsittelyketjun eri vaiheissa on usein mukana myös erilaisia yrityksiä. Vaatimukset elintarviketuotannossa ovat lisääntyneet viime vuosina samalla kun tuorekasvisten turvallisuus ja terveellisyys on noussut erityisen huomion kohteeksi. Kasviksia prosessoivat yritykset, viranomaiset ja kuluttajat tarvitsevat lisää tietoa käsitellyistä elintarvikkeista ja turvallisista käsittelymenetelmistä. Tuotannon laajeneminen alkutuotannosta jatkojalostukseen (esimerkiksi juuresten kuorintaan ja kasvisten pilkontaan), eli siirtyminen alkutuotannosta elintarvikehuoneistoon, lisää merkittävästi tiedon ja osaamisen tarvetta yrityksissä.

Kasviksia prosessoitaessa kasviksen pinta rikkoutuu ja tuote on herkkä erilaisille epäpuhtauksille. Mikrobit voivat päästä vihanneksiin ja lisääntyä niissä missä tahansa tuotanto-, varastointi- ja myyntiketjun vaiheessa. Kasviksia prosessoivien yritysten tuotantolinjoilla erilaisten mikrobien esiintyminen erityisesti tuotteiden kanssa kosketuksiin joutuvilla pinnoilla muodostaa riskin tuoteturvallisuudelle. Tuotteiden kanssa epäsuorassa kosketuksessa olevat pinnat voivat kontaminoida tuotteita välillisesti erityisesti korkean hygienian alueella. Useissa kansainvälisissä tutkimuksissa (Ilic ym. 2008, Little ja Gillespie 2008, Ilic ym. 2012) on havaittu hygieniaan, riittämättömään sanitaatioon ja vääriin tuotantotapoihin liittyviä ongelmia tuoretuotteiden elintarviketurvallisuudessa. Tuotantotilojen suunnittelussa on tärkeää ottaa huomioon laitoksen hygienia, laitteiden puhtaanapito (Torriano ja Massa 1994, Rapanello ym. 2009, Todd ym. 2010, Lehto ym. 2011), henkilöstön hygienia, erityisesti työntekijöiden käsihygienia (Torriano ja Massa 1994, Michaels ja Todd 2005, Fonseca 2006, Todd ym. 2010) sekä henkilöstökoulutus (Arvanitoyannis ja Kassaveti 2009).

Tämän tutkimuksen hygieniakartoitusten tavoitteena oli tuottaa kokonaiskuva kasviksia jatkojalostavien yritysten tuotantotilojen pintojen puhtaustasosta Tuovi-hankkeen alussa vuonna 2009 (Lehto ym. 2011) ja lopussa vuonna 2012 (Kuisma ym. 2014). Mittaustulokset antoivat tietoa pintojen puhtaudesta ja ongelmakohdista. Kartoitusten pohjalta yrityksillä on mahdollisuus puuttua epäkohtiin, tehostaa hankalasti puhdistettavien pintojen puhtaanapitoa ja korjata haitallisia käytäntöjä.

\section{Aineisto ja menetelmät}

Hygieniakartoitukset tehtiin vuosina 2009 ja 2012 kuudessa kasviksia prosessoivassa laitoksessa, joissa kasvikset pestään, kuoritaan ja pilkotaan erilaisiksi tuorekasvistuotteiksi. Kaikki jatkojalostusyritykset käsittelivät porkkanoita ja muita vihanneksia 500000 - 15000000 kiloa vuodessa. Jatkojalostusyritykset poikkesivat kuitenkin huomattavasti toisistaan toimintojen, prosessien ja kapasiteetin suhteen, kuten on kuvattu aiemman tutkimuksen julkaisussa (Lehto ym. 2011). Mukana oli yrityksiä, jotka sekä tuottavat raaka-aineen että prosessoivat sen valmiiksi tuotteiksi, sekä yrityksiä, jotka jatkojalostavat esikäsiteltyä raaka-ainetta. Vuonna 2012 tutkitut kohteet olivat samoja kuin vuonna 2009. Kussakin kartoituksessa tehtiin 264-696 mittausta. Mittausten kokonaismäärään vaikutti jatkojalostusyrityksen koko. Vuoden 2009 kartoitukset on kuvattu Lehdon ym. (2011) artikkelissa.

Yrityksissä käytiin suunnittelukäynnillä ennen hygieniakartoitusta. Tällöin laadittiin kirjallinen, valokuvin varustettu näytteenottosuunnitelma. Hygieniakartoitukset toteutettiin näytteenottosuunnitelmien mukaisesti, ottaen huomioon kohteen yksilölliset piirteet näytteenottotilanteessa. Kartoituksissa keskityttiin mahdollisiin kasvisten mikrobiologisen laadun kannalta kriittisiin näytteenottokohtiin ja tuotantoympäristön pintoihin, joita olivat esimerkiksi koneet ja laitteet, altaat, työtasot, katkaisijat ja siivousvälineet.

Mikrobiologiset pintanäytteet otettiin valituista näytteenottopisteistä käyttäen Orion Diagnostican Hygicult@-kontaktilevyjä, joilla tutkittiin aerobisten mikrobien kokonaismäärää (TPC) sekä enterobakteerien ja ß-glukuronidaasi-entsyymejä tuottavien lajien (E/ß-Gur) sekä hiivojen ja homeiden kokonaismäärää (Y\&F). ATP-bioluminesenssi-pintanäytteet otettiin vanupuikolla reagenssiputkiin, joiden kyveteistä mitattiin välittömästi ATP-bioluminesenssi luminometrisesti HY-LiTE®2-laitteella 
(ATP=adenosiinitrifosfaatti). Syntyneen valon intensiteetti luettiin näytöltä suhteellisina valoyksikköinä RLU (relative light units). RLU on suoraan verrannollinen ATP:n ja siten biologisen aineksen aiheuttaman kontaminaation määrään. Näytteenotot suoritettiin valmistajan ohjeiden mukaisesti. Tulosten tulkinnassa käytetyt raja-arvot ja viitteet tulosten luokittelemiseksi on esitetty yksityiskohtaisesti Lehdon ym. (2011) artikkelissa.

Tulokset kerättiin Excel-tietokantaan ja jaettiin viiteen ryhmään, kuten edellisessä tutkimuksessa (Lehto ym. 2011). Ryhmissä 1, 2 ja osittain ryhmässä 3 (kuljetinhihnat) pinnat olivat suoraan kosketuksessa tuotteeseen.

1) Koneiden pinnat, kuten leikkurit, kuorintakoneet jne.

2) Tuotteen kanssa kosketuksissa olevat pinnat, muut kuin koneet, mukaan lukien erilaiset pöydänpinnat, leikkuulaudat, veitset jne.

3) Kuljetinhihnat

4) Pakatut lopputuotteet

5) Pinnat, jotka eivät ole suorassa kosketuksessa tuotteiden kanssa, kuten ohjauspaneelit, sisäympäristön pinnat (esim. ovien kahvat, näytöt, vaa'at, lattiat, siivousvälineet).

\section{Tulokset ja tulosten tarkastelu}

Hygieniakartoituksissa havaittiin, että varsinkin erilaisten laitteiden ja pintojen puhdistettavuuteen sekä tuotantotilojen säännölliseen ja perusteelliseen puhdistukseen sekä desinfiointiin tulisi kiinnittää erityistä huomiota. Hygieniataso vaihteli yritysten välillä. Korkeimmat keskimääräiset kokonaismikrobimäärät, hiivojen, enterobakteerien ja ß-glukuronidaasipositiivisten bakteerien määrät todettiin vuonna 2009 koneiden ja laitteiden pinnoilta (Lehto ym. 2011). Vuonna 2012 keskimääräiset kokonaismikrobien, hiivojen, enterobakteerien ja $\beta$-glukuronidaasipositiivisten bakteerien määrät olivat kaikkien mittauskohteiden osalta alhaisemmat kuin edellisissä kartoituksissa. Poikkeukena olivat kuljetinhihnojen enterobakteerien ja ß-glukuronidaasipositiivisten bakteerien määrät, jotka olivat vuonna 2012 vuoden 2009 tasoa (kuvat 1 ja 2).

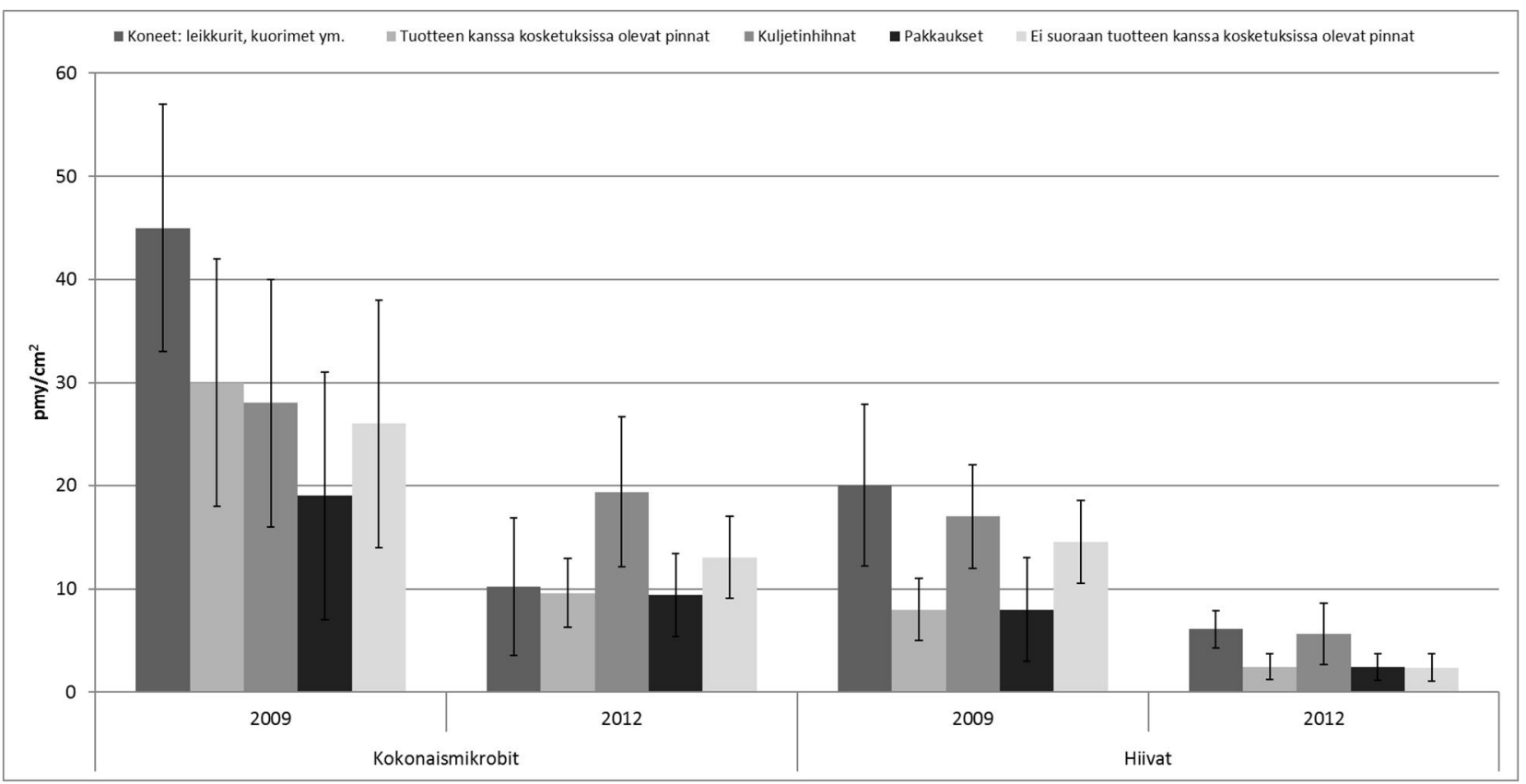

Kuva 1. Mikrobiologiset pintahygieniatulokset: kokonaismikrobit ja hiivat. Pylväs $=$ keskiarvo, jana $=$ keskiarvon keskivirhe ( \pm SE). Vuoden 2009 tulokset on esitetty alun perin lähteessä Lehto ym. (2009), vuoden 2012 tulokset ja molempien vuosien vertailu lähteessä Kuisma ym. (2014). 


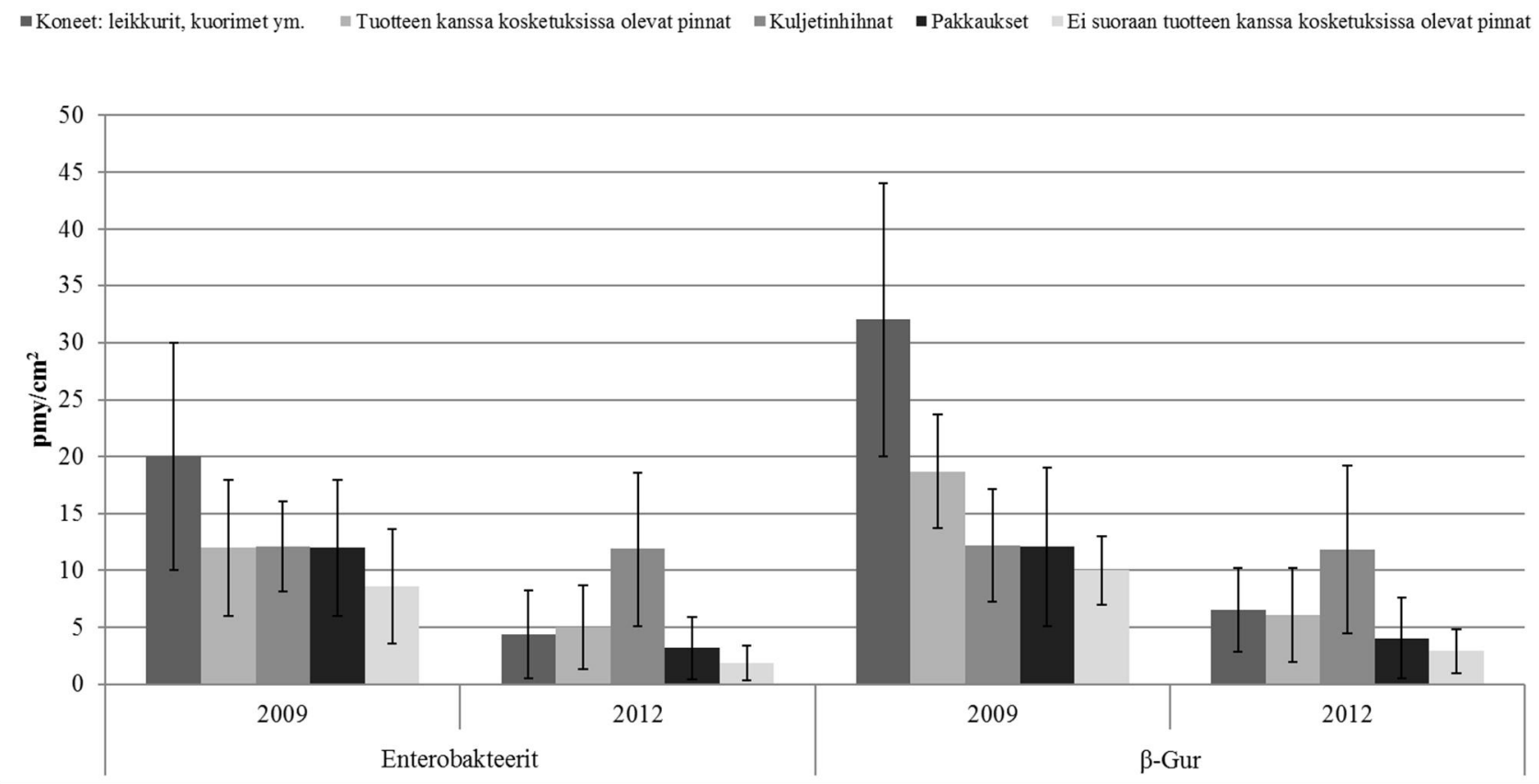

Kuva 2. Mikrobiologiset pintahygieniatulokset: enterobakteerit ja ß-Gur. B-Gur = ß-glukuronidaasi-entsyymejä tuottavien lajien kokonaismäärä. Pylväs = keskiarvo, jana = keskiarvon keskivirhe $( \pm$ SE). Vuoden 2009 tulokset on esitetty alun perin lähteessä Lehto ym. (2009), vuoden 2012 tulokset ja molempien vuosien vertailu lähteessä Kuisma ym. (2014).

Korkeat keskimääräiset ATP-arvot, jotka kuvaavat eloperäisen lian määrää pinnoilla, todettiin vuonna 2009 koneiden ja pakkausten pinnoilta sekä pinnoilta, jotka eivät olleet tuotteen kanssa kosketuksissa. Vuonna 2012 koneista mitatut keskiarvotulokset olivat aiempiin mittauksiin verrattuna parantuneet, kun taas kuljetinhihnojen ja pakkausten sekä pintojen, jotka eivät ole suoraan kosketuksissa tuotteen kanssa, keskimääräinen hygieniataso oli heikentynyt. Hajonnat olivat osin hyvin suuria. ATP-bioluminesenssimenetelmä on hyvin herkkä, joten pienetkin erot pintojen eloperäisessä likaantumisessa tulevat esille. Vuonna 2009 puisten varastolaatikoiden, vuonna 2012 puolestaan saavien muovihuppujen muista poikkeavan korkeat ATP-arvot vaikuttivat selvästi keskiarvotuloksiin (kuva 3). 


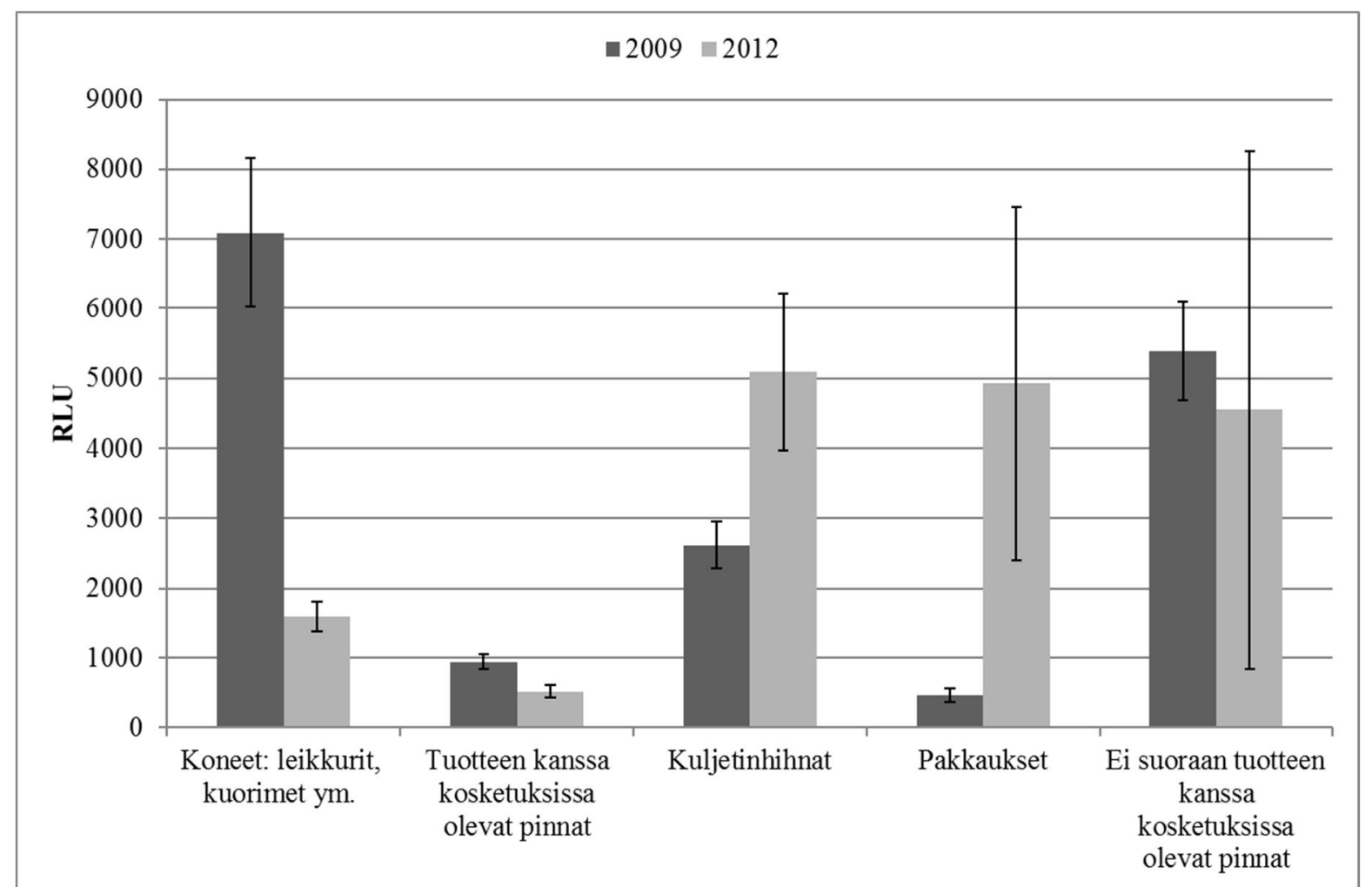

Kuva 3. Eloperäinen lika pinnoilla: ATP-bioluminesenssitulokset (RLU = suhteellinen valoyksikkö). Pylväs = keskiarvo, jana = keskiarvon keskivirhe $( \pm$ SE). Vuoden 2009 tulokset on esitetty alun perin lähteessä Lehto ym. (2009), vuoden 2012 tulokset ja molempien vuosien vertailu lähteessä Kuisma ym. (2014).

Verrattaessa kaikkien pintahygieniamenetelmien ja jatkojalostusyrityksien tuloksia havaittiin, että hyviksi luokiteltujen tulosten osuus tuotteiden kanssa kosketuksissa olevien pintojen osalta oli vuosien 2009 ja 2012 välillä noussut $39 \%$ :sta $60 \%$ :iin, koneiden tulosten osalta $22 \%$ :sta $39 \%$ :iin sekä pakkauksien osalta $20 \%$ :sta $32 \%$ :iin. Yleisesti ottaen vähäistä tulosten parantumista havaittiin kuljetinhihnojen kohdalla: hyviksi luokiteltujen tulosten osuus vuonna 2009 oli $23 \%$, vuonna $201225 \%$.

Kartoitukset osoittivat, että on tärkeää kiinnittää huomiota myös puhtaanapidon perusasioihin. Niitä käsitellään tarkemmin tuorekasvisalalla laaditussa puhtausoppaassa (Kuisma ym. 2012). Hygieniakartoituksien jälkeen TuoPro-hankkeessa on valmistunut Hyvän käytännön ohje tuorekasviksia pilkkoville yrityksille (Lehto ym. 2015). Hyvän käytännön ohjeen aihealueista järjestetään vuoden 2016 alkupuolella TuoPro2-hankkeessa tiedotus- ja koulutustilaisuuksia kasviksia prosessoiville yrityksille (TuoPro2 2015). TuoPro2-hankkeen rahoittaa Maa- ja metsätalousministeriö ja toteuttavat Helsingin yliopiston maataloustieteiden laitos ja Luonnonvarakeskus (Luke).

\section{Johtopäätökset}

Mikrobeja, biofilmejä ja puhdistusainejäämiä voi jäädä pinnoille, jos puhdistusprosessia ei tehdä asiamukaisella tavalla. On tärkeää varmistaa, että tuotteen kanssa kosketuksissa olevat pinnat on hyvin puhdistettu. Lisäksi myös pinnat, jotka eivät ole suoraan kosketuksissa tuotteeseen täytyy puhdistaa säännöllisesti ja esim. lattiakaivot on puhdistettava kunnolla, jotta mahdolliset taudinaiheuttajat ja muut epäpuhtaudet eivät pääse sitä kautta kulkeutumaan ja leviämään tuotantotiloihin. Omavalvontaohjeen ja hygieenisten toimintatapojen noudattaminen on tärkeää elintarvikkeiden turvallisuuden kannalta. Ensimmäisten hygieniakartoitusten tulosten perusteella todettiin, että kasviksia käsittelevissä laitoksissa tulisi kiinnittää erityisesti huomiota pintojen ja tilojen puhdistukseen sekä tehostaa omavalvontaa sekä lisätä näytteenottopisteitä ja -tiheyttä. Tämän tutkimuksen tulokset osoittavat, että yleinen tuotantotilojen pintahygienia kuudessa vihanneksia prosessoivassa yrityksessä oli vuoden 2012 kartoituksissa kohentunut verrattuna vuoden 2009 tuloksiin. Tämä tulos on todennäköisesti ainakin osittain seurausta 
ohjeista ja parannusehdotuksista, joita annettiin ensimmäisen hygieniakartoituksen yhteydessä. Yrityksissä oli tehty erilaisia toimenpiteitä hygienian parantamiseksi, esimerkiksi ongelmallisten laitteiden puhdistusta oli tehostettu, kuluneita pintoja vaihdettu uusiin ja tilojen puhdistusainekäytäntöihin oli kiinnitetty huomiota.

\section{Kirjallisuus}

Arvanitoyannis, I. S. \& Kassaveti, A. 2009. HACCP and ISO 22000 - A comparison of the two systems. In: Arvanitoyannis (ed.), I. S. HACCP and ISO 22000: Applicationto foods of animal origin Oxford: Wiley-Blackwell Limited, pp. 3-45.

Fonseca, J. M. 2006. Postharvest handling and processing: Sources of microorganisms and impact of sanitizing procedures. In: Matthews K. R. (ed.), Microbiology of fresh produce. Washington, DC: ASM Press, pp. 85-120.

Ilic, S., Odomeru, J. \& LeJeune, J. T. 2008. Coliforms and prevalence of Escherichia coli and foodborne pathogens on minimally processed spinach in two packing plants. Journal of Food Protection 71 (12), pp. 2398-2403. Ilic, S., Rajić, A., Britton, C. J., Grasso, E., Wilkins, W., Totton, S., et al. (2012). A scoping study characterizing prevalence, risk factor and intervention research, published between 1990 and 2010, for microbial hazards in leafy green vegetables. Food Control 23 (1), pp. 7-19.

Kuisma, R., Pienmunne, E., Lehto, M., Mäki, M. \& Kymäläinen, H-R. 2012. Puhtausopas tuore-vihannesten tuotantolaitoksille. Helsingin yliopisto, Maataloustieteiden laitoksen julkaisuja 11/2012

Lehto, M., Kuisma, R., Määttä, J., Kymäläinen, H-R. \& Mäki, M. 2011. Hygienic level and surface contamination in fresh-cut vegetable production plants. Food Control 22, pp. 469-475.

Lehto, M., Maarit, M., Kuisma, R. \& Kymäläinen, H.-R. 2015. Hyvän käytännön ohje tuorekasviksia pilkkoville yrityksille. Luonnonvara- ja biotalouden tutkimus 10/2015, Luonnonvarakeskus (Luke), verkkojulkaisu osoitteessa http://urn.fi/URN:ISBN:978-952-326-09-2. 129 s.

Little, C. L. \& Gillespie, I. A. 2008. Prepared salads and public health. Journal of Applied Microbiology 105 (6), pp. 1729-1743.

Michaels, B. \& Todd, E. 2005. Food worker personal hygiene requirements during harvesting, processing, and packaging of plant products. Microbial hazard identification in fresh fruit and vegetables. John Wiley \& Sons, Inc., pp. 115-153.

Rapanello, E., Fuzihara, T. O., Nunes, S. M., Daros, V. d. S. M. G. \& Savignano, L. V. 2009. Hygienic conditions of minimally-processed watercress, lettuce and cabbage, and fresh-cut lettuce. Revista do Instituto Adolfo Lutz (Impresso) 68, pp. 83-90.

Tike (Luke tietopalvelu) 2014. Elintarvikkeiden kulutus henkeä kohti vuonna 2013, ennakkotiedot. 27.6.2014. http://stat.luke.fi/ravintotase?q=ravintotase

Todd, E. C. D., Michaels, B. S., Greig, J. D., Smith, D., Holah, J. \& Bartleson, C. A. 2010. Outbreaks where food workers have been implicated in the spread of foodborne disease. Part 7. Barriers to reduce contamination of food by workers. Journal of Food Protection 73 (8), pp. 1552-1565.

Torriano, S. \& Massa, S. 1994. Bacteriological survey on ready-to-use sliced carrots. Food Science and Technology-Lebensmittel-Wissenschaft \& Technologie 27 (5), pp. 487-490.

TuoPro2 2015. TuoPro2-hankkeen seminaarit vuonna 2016. Verkkosivu http://tuopro2.weebly.com/blogi/tuopro2-hankkeen-seminaarit-vuonna-2016 Hyviä käytäntöjä tuorekasviksia käsitteleviin yrityksiin - TuoPro2, Luotu 2015, viitattu 2.12.2015. 